DOI https://doi.org/10.18551/rjoas.2018-09.04

\title{
ACCESSIBILITY, FINANCIAL RISK PERCEPTION AND FARMERS' SATISFACTION TO MICROFINANCE SERVICES QUALITY IN DEVELOPING COUNTRIES
}

\author{
Shinta Agustina, Fitra Rizky, Pratiwi Destyana, Haryati Novi \\ Department of Agricultural Social Economics, Faculty of Agriculture, University of Brawijaya \\ ${ }^{*}$ E-mail: shint471ub@yahoo.com
}

\begin{abstract}
Government provides many farming finance loan programs to farming community, but many farmers still feel that financial institutions that are given trust by the government are difficult to access. Thus, this study aims: first, to reveal farmers 'assumptions about accessibility, secondly to analyze risk perceptions of micro finance and the final goal is to analyze whether microfinance services can satisfy farmers' needs. This research was conducted on two groups of farmers, such as rice farmers in Singosari District and orange farmers in Dau District, Malang Regency, East Java Province, Indonesia. Data analysis method uses quantitative descriptive, with the use of farmer perceptions scoring regarding accessibility dimensions, namely affordability, impact and sustainability, and perception of financial risk, while service quality dimensions are Tangibles, Reliability, Responsiveness, Assurance, Emphaty by using SEM-PLS analysis. Both rice farmers and orange farmers have good accessibility, but there are differences in the actions of borrowing funds from the two groups of farmers. Rice farmers do not dare to borrow funds if they have not coordinated with farmers' group association, while orange farmers dare to borrow individually. At present, farmers are getting a loan from one of the government programs, and the results of the study indicate that the risk is very low if borrowing is done through a farmers' group association. While the results of the analysis of the quality of microfinance services that are closely related to the satisfaction of orange farmers as borrowing customers are the dimensions of Reliability, Assurance and Emphaty. Although the service dimensions are positively related to satisfaction, there are several indicators that microfinance must improve so that farmers are more satisfied with the government programs mandated by the institution. Indicators that must be corrected by microfinance are employees 'knowledge of government programs in detail and giving more attention to farmers' customers.
\end{abstract}

\section{KEY WORDS}

Accessibility, quality of service, perception of financial risk, farmer satisfaction, microfinance.

Accessibility to capital resources is still limited, especially for farmers who control narrow land which is the largest community of rural communities and small-scale business actors [1]. Credit is an important factor in production activities, because credit can increase farm operational size and resource productivity [2]. In addition, credit can facilitate innovation adoption activities that can increase farm production and profits so that capital formation occurs.

Credit is many people's choice as a way to meet the ever-increasing needs, including the agricultural sector. Inadequate income, encouraging the trend of lending to tend to increase, both in formal financial institutions and informal institutions. The availability of access to finance provides opportunities for farmers to buy inputs or other capital to increase productivity and income in the future [3].

However, this access has not been fully enjoyed by farmers. The agricultural sector only receives $6.92 \%$ with an interest rate of $11.6 \%$ of the total loans disbursed by commercial banks. Distribution through the People's Financing Bank that distributed loans was only $17.60 \%$ with an interest rate of $33.35 \%$ of the total loans granted. Credit disbursement is far different from the trade sector which gets a credit of $25.53 \%$ with an interest rate of $12.99 \%$ in commercial banks [4]. Low lending in the agricultural sector, because this sector is considered to have high risk by the microfinance sector so they need to be cautious. The 
risks faced by this sector include the risk of crop failure, price fluctuations and businesses that depend on weather factors, and it is very difficult to accurately calculate cash flow and do not have adequate guarantees [5].

The reason for formal financial institutions not to give credit to farmers is due to uncertainty and time lag in the production process [6] which does not allow farmers to pay credit by the usual mechanism. This was also caused by: (a) Experience and trauma of several banks facing the reality of non-performing loans during credit disbursement; (b) Central bank regulations in Indonesia are quite strict so that prudent banks in the distribution of funds; and (c) Many banks (especially large banks) that do not have the experience of distributing microcredit [7].

The government has sought to help alleviate the capital burden of farmers and small businesses by establishing various financing schemes that are easily accessible so that they can have a positive impact on the development of smallholder farmers and businesses in Indonesia. Financial institutions have great potential in supporting farmers' financing because formally is a financial intermediary institution [5]. The banking sector supports the implementation of national government programs in order to improve equity, economic growth and national stability.

However, can this intermediary institution be easily accessible to farmers? And what about the perception of farmers' risk to microfinance? And what about the quality of microfinance services to farmers? Where, the quality of service is an effort to fulfill the needs and desires of consumers as well as the accuracy of delivery in keeping up with consumer expectations [8].

\section{LITERATURE REVIEW}

Farmers are said to have access to a credit source if they are able to borrow (have credit worthy) [9]. If farmers cannot borrow because of various constraints (credit constraints), the farmer does not have access to credit sources. The performance of a microcredit channeling institution is said to be accessible, can be measured from three categories, namely outreach, impact and sustainability, which are referred to as the triangle of microfinance [10]. Microfinance institutions in expanding outreach to farmers are determined by the institution's ability to maintain financial sustainability. So that the financial institution has a positive multiplier effect on economic development ranging from the environment of the financial institution to the national environment.

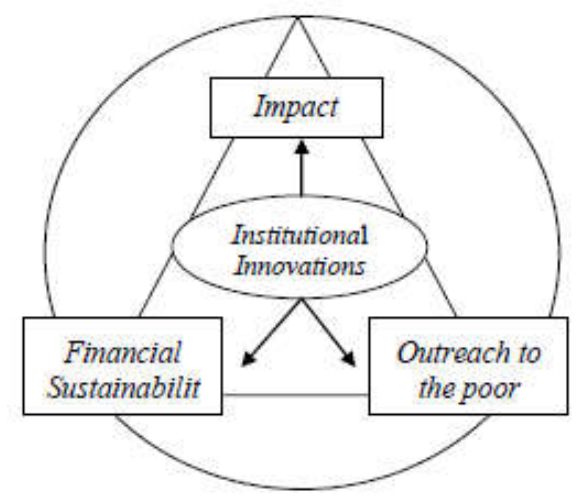

Figure 1 - Triangle of Microfinance ${ }^{[10]}$

Informal capital sources as an alternative for farmers and business people, often impose requirements standards that are less suitable for the needs of all economic sector actors in their contract letters. Actors from the agricultural sector, for example, often suffer losses due to inflexible credit contracts. In fact, micro-finance institutions or non-bank MFIs generally provide loans to landless farmers and require returns as soon as possible after a loan is granted. Strict payment schedules also often encourage farmers to undertake long- 
term investments, given the longer production cycle in the agricultural sector than other economic activities. As a result, farmers are faced with routine payment obligations and risks related to climatic conditions.

Thus, the Indonesian government still plays an important role in the capital of farmers and forces MFIs to either banks or non-banks to serve farmers. So, it is very important to analyze the quality of microfinance services to farmers' satisfaction. There are five dimensions of service quality [11] used in this study are:

- Tangibles are services that are seen from the appearance of physical facilities, equipment, personnel, and communication materials;

- Reliability is the ability to perform guaranteed and accurate services;

- Responsiveness: namely Willingness to provide fast service and help customers.;

- Assurance The ability of employees to express trust and confidence and confidence in the level of their respective knowledge;

- Empathy is a service that is viewed from individual attention given by the company to its customers.

Satisfaction [12] is a feeling of pleasure or disappointment that arises because of comparing the perceived performance of the product (or outcome) to their expectations. If performance fails to meet customer expectations, the customer feels dissatisfied. If the performance is in line with expectations, then the customer will be very satisfied.

So the hypothesis of the third objective of this study are:

$\mathrm{H} 1$ : Tangibles has a significant positive correlation with farmers' satisfaction;

$\mathrm{H} 2$ : Reliability relates significantly positively to farmers' satisfaction;

H3: Responsiveness relates significantly positively to farmers' satisfaction;

H4: Assurance has a significant positive correlation with farmers' satisfaction;

H5: Emphaty has a significant positive correlation with farmers' satisfaction.

This research aims to describe farmers' access to capital loans at financial institutions; analyze farmers' perceptions of risk in microfinance; analyze the relationship between service quality dimensions to the farmers' satisfaction.

\section{METHODS OF RESEARCH}

Respondents were 34 rice farmers in Watugede Village, Singosari Sub District and 40 Orange farmers in Gading Kulon Village, Dau Sub District, Malang Regency, East Java, Indonesia. The study was conducted in April - June 2018. Data analysis methods using SEM-PLS using Warp PLS 5.0.

\section{RESULTS AND DISCUSSION}

Rice farmers in Singosari Subdistrict obtain financing from the government under the name "Hulu Hilir" Program, which is coordinated by Makmur Santoso Group Farmers Association through Government Bank. The farmers' perception of the accessibility of microfinance through Gapoktan is as follows: Aspect Outreach: as many as 73.1 farmers stated that loan access is easy to reach, $61.5 \%$ of farmers said they were not reluctant to borrow, and $92.4 \%$ of farmers stated that lending conditions were easy; Impact Aspect, as many as $65 \%$ of farmers stated that the loans had a significant impact on farming and $61.5 \%$ of farmers stated that loans had an impact on household use; Aspect Sustainability, as many as $90 \%$ of farmers do not know whether this loan will continue in the next planting season.

The government provides the "Kredit Usaha Rakyat (KUR)" program and many orange farmers access it independently. Meanwhile, the perception of accessibility to the Government Bank appointed to carry out these services is as follows: Aspect Outreach: as many as 87.5 farmers stated that access to loans is easily accessible and $85 \%$ of farmers stated that the information came from farmer groups; Impact Aspect, as many as $77.5 \%$ of farmers stated that the loans had an impact on farming and Sustainability Aspects showed that as many as $90 \%$ of farmers wanted to continue loans for their farming needs. 
Research shows that rice farmers do not dare to access their own financial loans to microfinance, so the tendency of farmers' risk perception leads to associations of farmer groups that administer administration. Based on this, $88.4 \%$ of farmers stated that they did not risk lending procedures, $65.4 \%$ found no risk to the length of the disbursement process, $88.5 \%$ considered that farmer groups association could be trusted, $69.2 \%$ assumed that collateral was not a risk, $53.86 \%$ stated that farmers did not at risk of loan repayment, $53.9 \%$ of farmers will use loans for their farms, and $57.7 \%$ of farmers say interest rates are not risky.

The constraints felt by orange farmers are the value of insurance that is too high that burdens the respondents to pay. In addition, there are respondents who say that the money spent on administration differs significantly from other respondents.

This analysis is not carried out on rice farmers, it is feared that the answer is bias towards the quality of service by farmer groups associations and not to microfinance. Analysis was carried out on orange farmers with the following results: SEM stages have been carried out well, Reliability indicator value has been eliminated. Reflective indicators have fulfilled the first requirement of reliability because the value of the loading factor has been above 0.7 with a significance value of P-value below $5 \%$. While considering the value of Indicator Reliability and Composite Reliability, the evaluation of measurement model also considers the value of Average Variant Extracted (AVE). Recommended AVE values must be greater than 0.5 or $50 \%$. R-Squares value shows a value of 0.650 , thus, it can be concluded that the relationship between exogenous dimensions and endogenous is good. Adj Value. R-Squared meets SEM-PLS criteria and has a strong model. The full collinearity value of VIF indicates that the remote dimension is a collinearity problem. Q-Squared shows the number 0.621 it can be concluded that the model used in this model has predictive relevance because it is greater than 0 . Based on the structure model that is formed that there are three dimensions that are significantly positive with the satisfaction of farmers as customers, namely the dimensions of Reliability, Assurance, and Empathy has a positive and significant relationship with consumer satisfaction of $0.39,0.45$, and 0.33 with a significance value of $<0.01$.

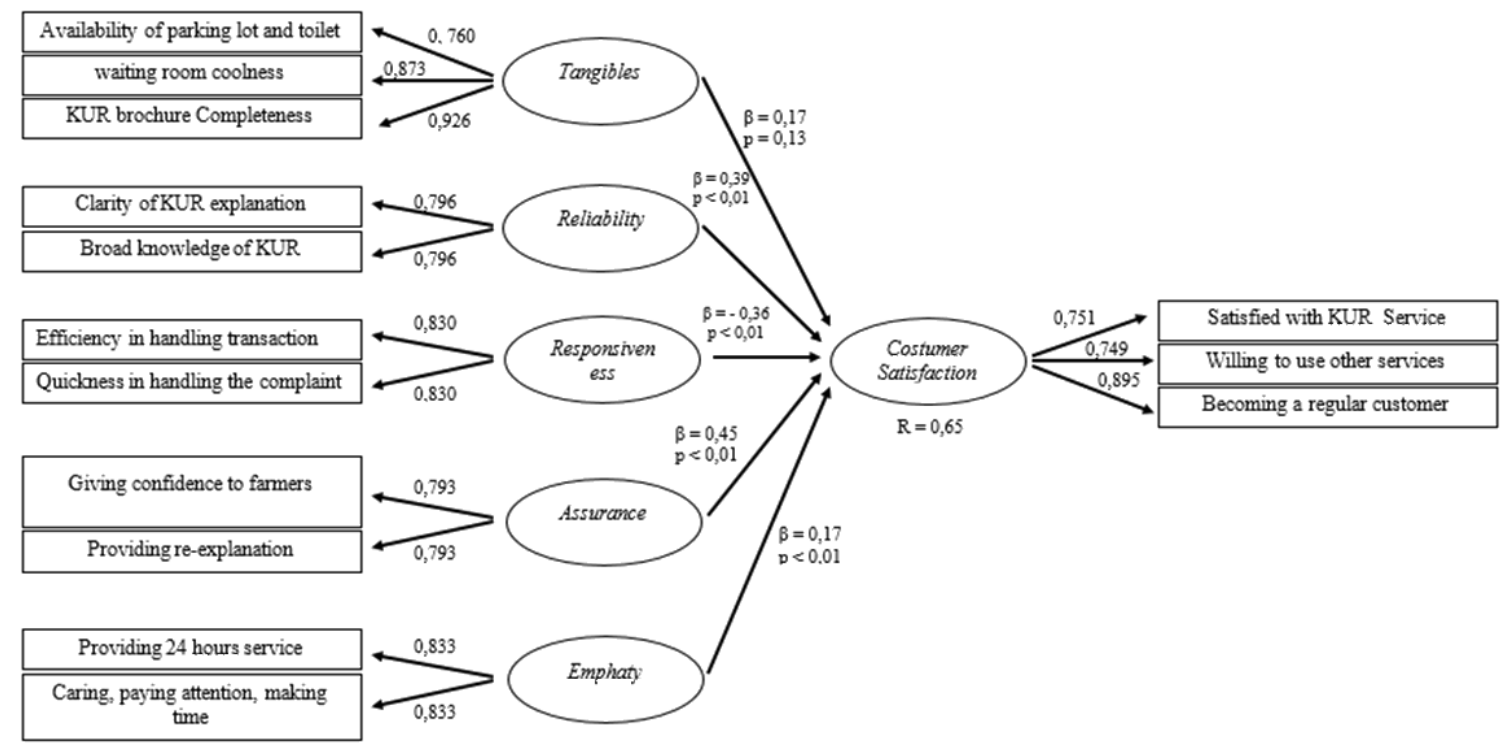

Figure 1 - Structural Model (Source: Primary Data Processed, 2018)

\section{CONCLUSION}

Microfinance has been well accessed by farmers, even though rice farmers must be assisted by farmer groups association. Farmers state that when dealing with microfinance will not be risky. Three dimensions of service quality that are significantly positively related to satisfaction of orange farmers, namely the dimensions of Reliability, Assurance and Empathy 
with each relationship of $39 \%, 45 \%$ and $33 \%$. This means that the improvement of services in these three dimensions will be followed by the increasing satisfaction of farmers as customers.

Managerial implications:

Building the capacity of agricultural institutions is very beneficial for the financial development of farming;

For microfinance, it is expected to maintain trust by increasing and paying attention to services in terms of alertness in handling transactions and complaints of farmers. Another indicator that must be improved by microfinance is the knowledge of employees regarding the government program in detail and giving more attention to farmers' customers;

For the Government, the program of granting capital to farmers is considered effective so that there needs to be new innovations related to the capital of farmers in order to create economic stability, especially in agriculture.

\section{ACKNOWLEDGEMENTS}

We would like to thank Indonesian Ministry of Research, Technology and Higher Education and University of Brawijaya especially the Research and Community Services Institution.

\section{REFERENCES}

1. Hastuti, E. L. 2006. Kajian Sistem Pembiayaan Mikro Pertanian. Pusat Analisis Sosial Ekonomi dan Kebijakan Pertanian, Pusat Penelitian dan Pengembangan Sosial Ekonomi Pertanian, Departemen Pertanian, Bogor.

2. Nwaru et. al. 2006. Relative Technical Efficiency of Credit and Non-Credit User Crop Farmers. African Crop Science Journal, Vol. 14, No. 3, pp: 241-251.

3. Yehuala, Sisay. (2008). Determinants Of Smallholder Farmers Access To Formal Credit: The Case Of Memeta Woreda, North Gondar, Ethiopia. A Thesis of the Agriculture Department of Rural Development and Agricultural Extension School, Haramaya University

4. Otoritas Jasa Keuangan. 2015. Statistik Perbankan Indonesia. ISSN: 2089-2954, Vol. 13.

5. Ashari dan Saptana. 2005. Prospek Pembiayaan Syariah Untuk Sektor Pertanian. Forum Penelitian Agro Ekonomi Vol. 23 No. 2, Desember 2005: 137-140.

6. Anggraeani L. 2009. The Function of Social Networks for Informal Credits in Remote Rural Areas in Indonesia (Disertasi). Tokyo (JP). The University of Tokyo.

7. Indiastuti, R. Arti Tahun Keuangan Mikro bagi Indonesia. http://www.pikiranrakyat.com/cetak/2005/0305/08/0608.htm [12/07/06]

8. Tjiptono, Fandy. 2007. Strategi Pemasaran. Edisi Pertama. Yogyakarta: Andi Ofset.

9. Diagne $A$ and $M$ Zeller. 2001. Access to Credit and Its Impact on Welfare in Malawi [Laporan Penelitian]. Washington DC (AS): International Food Policy Research Institute Report 116.

10. Zeller, M. dan Meyer, R.L. 2002. The Triangle of Microfinance: Financial Sustainability, Outreach and Impact. London: The John Hopkins University Press and The International Food Policy Research Institute (IFPRI)

11. Parasuraman, A., Zeithaml. 1991. SERVQUAL: A Multiple-item Scale for Measuring Consumer Perception of service Quality. Journal of Service Research

12. Kotler, P \& K. L. Keller. 2009. Manajemen Pemasaran. Jilid 1. Edisi ke-13. Jakarta: PT Erlangga. 